\title{
Imbibition, Germination and Vigor of Gymnanthes Klotzschiana Müll.Arg. Seeds Under Hypoxia
}

\author{
Émerson Couto da Rocha ${ }^{1}$ (1) 0000-0002-1022-680X \\ Luciana Magda de Oliveira ${ }^{1}$ (1) 0000-0001-7362-1041 \\ Vinícius Spolaor Fantinel ${ }^{1}$ (1) 0000-0002-0414-7486 \\ Romell Alves Ribeiro Dias ${ }^{1}$ (1) 0000-0003-2501-5025
}

\begin{abstract}
The objective of this study was to assess hypoxia tolerance in Gymnanthes klotzschiana seeds harvested in two areas (Area 1 - subject to flooding; and Area 2 - not subject to flooding) by the imbibition curve, vigor and germination. Seeds of the two areas were submitted to: one (T-1d), three (T-3d), five (T-5d), ten (T-10d) and twenty days under hypoxia (T-20d); in addition to the control (T-0d). All treatments presented three germination stages. The highest germination was achieved in Area 1 T-1d (90\%) and the lowest in Area 2 T-20d (31\%). The Area 1 seeds required less time and water content to finish their germination, and they presented greater tolerance to hypoxia; a fact proven by the germination and vigor results. G. klotzschiana seeds harvested in an area subject to flooding are more tolerant to hypoxia and are recommended for restoration projects in this type of area.
\end{abstract}

Keywords: environmental stress, submersion, flooding, branquilho.

\section{INTRODUCTION AND OBJECTIVES}

Gymnanthes klotzschiana popularly known as branquilho, is a tree species that belongs to the Euphorbiaceae family, and it can be found in the Caatinga, Cerrado, and Atlantic Forest biomes (JBRJ, [2018?]). Branquilho can occur naturally in wet and alluvial soils (Silva et al., 2012), and this species has the potential to recompose degraded areas (Ferreira et al., 2013).

Many forest recomposition projects are unsuccessful (Brancalion et al., 2010; Rodrigues et al., 2009) due to the poor knowledge about seeds and seedlings behavior in the new colonization areas (Gattringer et al., 2017), among other factors. Considering this, the selection of matrices and seeds is fundamental in this process of reestablishing a new selfsustaining mature forest, especially in flooded areas.

Germination is the resumption of embryonic axis growth after the seed physiologically detaches from the mother plant and finds favorable conditions to develop (Bewley et al., 2013). Seeds usually have a three-phase imbibition pattern during the germination process (Carvalho \& Nakagawa, 2012). The first phase is characterized by the reactivation of metabolism by water intake. The next phase is mainly differentiated by the low water intake in the seed. In the third phase more intense water reentry occurs, which culminates in forming a new seedling (Marcos-Filho, 2015).

Tropical and subtropical environments subject to flooding vary greatly in terms of duration, frequency and amplitude of flooding (Ferreira et al., 2009). As such, they create places with different adaptive needs for species. According to Kozlowski (1997), flooding can compromise germination by decreasing available oxygen in the substrate (hypoxia). However, this obstacles to germination depends on the species and also the flood time (Crawford \& Brandle, 1996). Hypoxia decreases the energy produced by seeds during germination, as ATP synthesis is less efficient when the fermentative route is activated (Bailey-Serres et al., 2012). This fact is explained for oxygen is the ultimate acceptor of electrons in the last phase of aerobic respiration. Thus, cells tend to use the fermentative route more often when oxygen is restricted or lacking for energy production (Kato-Noguchi, 2006). Tolerance to lack of oxygen on germination was tested on Carapa guianensis Aubl. seeds, and germination was higher than $70 \%$

${ }^{1}$ Universidade do Estado de Santa Catarina (Udesc), Lages, SC, Brasil 
(Scarano et al., 2003). In Himatanthus succubus (Spruce ex Müll.Arg.) Woodson seeds, a tree species typical of lowland areas, seedling formation reached $84 \%$ (Ferreira et al., 2006).

The objective of this study was to evaluate the hypoxia tolerance of G. klotzschiana seeds harvested in two areas (Area 1 - subject to flooding; and Area 2 - not subject to flooding) by the imbibition curve, vigor and germination.

\section{MATERIALS AND METHODS}

\subsection{Matrix selection, harvesting, extraction and seed processing}

Ripe fruits (dark brown in color) were harvested from selected mother trees without phytosanitary issues, with diameter at breast height $\geq 15 \mathrm{~cm}$ and at least $30 \mathrm{~m}$ apart, in two areas (lots).

Area 1, where 20 matrices were selected (Lat.: $-27.841221^{\circ}$ and Long.: $-50.234878^{\circ}$ ), is classified as an Alluvial Mixed Ombrophilous Forest (IBGE, 2012), and it is located in the municipality of Lages, SC. Area 1 is characterized by being an environment subject to periodic flooding, being in a lowland, following a river course. Area 2, where eight matrices were selected (Lat.: $-28.196411^{\circ}$ and Long.: $-50.752545^{\circ}$ ), is classified as Montana Semi-deciduous Seasonal Forest (IBGE, 2012), and it is located in Capão Alto, SC. This area is upstream from the Barra Grande hydroelectric dam, and it is not subject to periodic flooding because it is steep and higher. A larger number of matrices were selected in Area 1 as it presents high relative density of branquilho, aiming at greater sample representativeness. Approximately $350 \mathrm{~g}$ of seeds were collected per selected matrix in both areas.

After harvesting, the fruits were placed in plastic bags and sent to the Seed Laboratory of Santa Catarina State University to extract the seeds under shade of a canvas. The processing was performed using sieves and manually. The seeds were subsequently placed in glass containers, properly closed, and stored in a cold chamber $\left(10^{\circ} \mathrm{C}\right.$ and $\left.\mathrm{RH}=65 \%\right)$ for a maximum of five days.

\subsection{Hypoxia treatment}

In order to simulate water stress by flooding, 100 seeds were divided into four repetitions and placed in plastic cups with $60 \mathrm{~mL}$ of distilled water, which was renewed every 72 hours (h). Six treatments were defined: one day (T-1d), three days (T-3d), five days (T-5d), ten days (T-10d) and twenty days of hypoxia (T-20d), in addition to the treatment without the effect of simulated flooding (T-0d). The treatment definition was based on the study developed by Barddal (2006).

\subsection{Obtaining imbibition curves}

The imbibition curves were established during the germination process to verify the water absorption behavior in the different proposed treatments. The curves were obtained by the Equation 1 for each treatment:

Final weight $=\frac{\text { Initial weight } \times(100 \text { initial water level })}{100-\text { Final water level }}$

Weighing was performed within the first $24 \mathrm{~h}$ every $6 \mathrm{~h}$, and thereafter every $12 \mathrm{~h}$. Each curve was completed when at least $40 \%$ of the seeds of each repetition presented a $3 \mathrm{~mm}$ primary root.

\subsection{Physical and physiological analyses}

The following method was determined according to the rules for seed analysis (Regras para Análise de Sementes RAS) (Brasil, 2009): the dry mass before hypoxia treatments, in four replications of 50 seeds; and the water content of the seeds before and after each treatment, in two repetitions of five grams each. An electronic scale accurate to $0.001 \mathrm{~g}$ was used for weighing the samples, and an oven at $60^{\circ} \mathrm{C}$ for $24 \mathrm{~h}$ for drying to determine dry mass and an oven at $105^{\circ} \mathrm{C}$ for $24 \mathrm{~h}$ was used to obtain initial and final seed water content. After the drying period, the containers were placed in a desiccator containing silica gel for 10 minutes until they reached room temperature.

After exposure to hypoxia, the seeds were placed to germinate in plastic boxes $(11.0 \times 11.0 \times 3.5 \mathrm{~cm})$ on a blotter substrate and they were moistened to 2.5 times their weight. Germination was performed in a growth chamber containing four $25 \mathrm{~W}$ lamps, alternating temperature $\left(20 / 30{ }^{\circ} \mathrm{C}\right)$ and $12 \mathrm{~h}$ photoperiod (Santos \& Aguiar, 2005). Only seeds that generated normal seedlings were considered for the sum of the final germination percentage (Brasil, 2009).

Seeds that did not generate normal seedlings were classified as abnormal seedlings (rootless and/or without cotyledons and necrotized hypocotyl) and empty seeds as dead and non-germinated seeds. Seeds were sectioned longitudinally and immersed in a solution of 2,3,5 triphenyl chloride $0.1 \%$ tetrazolium for $2 \mathrm{~h}$ at $30^{\circ} \mathrm{C}$ to verify the viability of ungerminated seeds, according to the methodology suggested by Cosmo et al. (2010). The seeds that fully colored the hypocotyl 
radicle axis and the cotyledons were considered viable. Unstained seeds were classified as unviable.

Germination was monitored daily and the following tests were used to determine seed vigor: first germination count FGC (five days after the end of each treatment period); and germination speed index (GSI), which assessed as germinated the seeds that expanded the first pair of cotyledonary leaves. The GSI calculation was performed according to the equation proposed by Maguire (1962). All physiological analyzes were completed at 21 days after the submersion period.

\subsection{Statistical analysis}

Germination and vigor data were initially submitted to normality analysis by the Shapiro-Wilk Test, and then the factor analysis was performed (six treatments $\times$ two areas). The values generated were assessed by the F-Test and the means by the Scott-Knott Test (1974), both at a significance level of $\alpha=0.05$. Regression analysis was used to adjust the imbibition curves $(\alpha=0.05)$. The Sisvar statistical program was used for statistical analyzes.

\section{RESULTS AND DISCUSSION}

The seeds collected in Area 1 (subject to periodic flooding) presented initial water content of $8.9 \%$ and germination of $85 \%$. Seeds from Area 2 (not subject to periodic flooding) had 9.2\% initial water content and $84 \%$ germination. Water content and control germination did not differ statistically between areas. The dry mass at both collection sites was $0.085 \mathrm{~g} / 50$ seeds.

The seeds of all treatments followed the three-phase imbibition pattern for both collection areas (Figure 1). Considering only Area 1, the seeds reached $30 \%$ of water content in approximately $30 \mathrm{~h}$ at the end of the germination Phase I. The seeds presented low water uptake during Phase II. This phase was proportionally longer in treatments exposed to oxygen restriction for a longer period. The seeds of all treatments started Phase III germination with water content near to $35 \%$. Seeds that were not exposed to hypoxia (T-0d) began Phase III at approximately $70 \mathrm{~h}$ (radicle emission) after germination began. In seeds that remained for one day (T-1d), three days (T-3d), five days (T-5d), ten days (T-10d) and twenty days (T-20d) under hypoxia, Phase III started at approximately $84,132,160,252$ and $580 \mathrm{~h}$, respectively, after the beginning of the germination process.

The seeds collected in Area 2 completed germination Phase I with around $40 \%$ of water content, which was reached in approximately $24 \mathrm{~h}$ in all treatments. The seeds had a low water uptake during Phase II (similar behavior to Area 1 seeds). The seeds of all treatments presented water content close to $45 \%$ at the beginning of Phase III. Seeds that were not exposed to controlled flooding (T-0d) reached Phase III in approximately $100 \mathrm{~h}$. Phase III began at 124, 172, 220, 300 and $540 \mathrm{~h}$, for the T-1d, T-3d, T-5d, T-10d and T20d treatments, respectively (Figure 1).

The imbibition curve showed that seeds collected in Area 1 germinated faster and at the same time needed a lower water content to start and finish their germination process, regardless of the treatments assessed, compared to seeds harvested in Area 2. This is probably an adaptation developed by the species to flooding, because the faster the germination and formation of a seedling, the greater their chances to tolerate a flooded environment, as well as oxygen restriction. Seeds in this stress condition tend to increase the activity of some anaerobic respiration-related enzymes, such as alcohol dehydrogenase and pyruvate decarboxylase (Magneschi \& Perata, 2009). Metabolic and molecular reprogramming becomes critical to generate energy necessary for rapid germination and stretching of plants under hypoxic conditions (Narsai \& Whelan, 2013).

In relation to the germination stages, Phase $\mathrm{I}$ is a physical process, independent of seed viability (Wang et al., 2015). The water intake in the seeds at this stage was fast in all treatments and in the two lots assessed - possibly because the large difference in water potential between the seed and the substrate. This accelerated water intake did not affect the seed germination of either collection area, since they presented similar germination to the treatment without the influence of simulated flooding (T-0d) as shown in Table 1.

This may show a positive ability of G. klotzschiana seeds to efficiently rearrange their membrane structures. According to Bewley et al. (2013), seeds that support low water contents at the end of the maturation process (orthodox), such as branquilho, present reducing sugars and oligosaccharides that interact with proteins and hydrophilic functional groups in the membranes, maintaining compartmentalization and cellular functionality. Maintaining cell integrity is associated with the ability of seeds to reorganize more efficiently and thus preserve their physiological quality (Villa-Hernández et al., 2013; Weitbrecht et al., 2011).

The higher water content presented by seeds collected in Area 2 at the end of Phase I and until the end of germination could be explained by the lower restriction to water entry by the seed coat, probably due to the lower vigor of these seeds (Table 1) (Bewley et al., 2013; Li et al., 2014). 

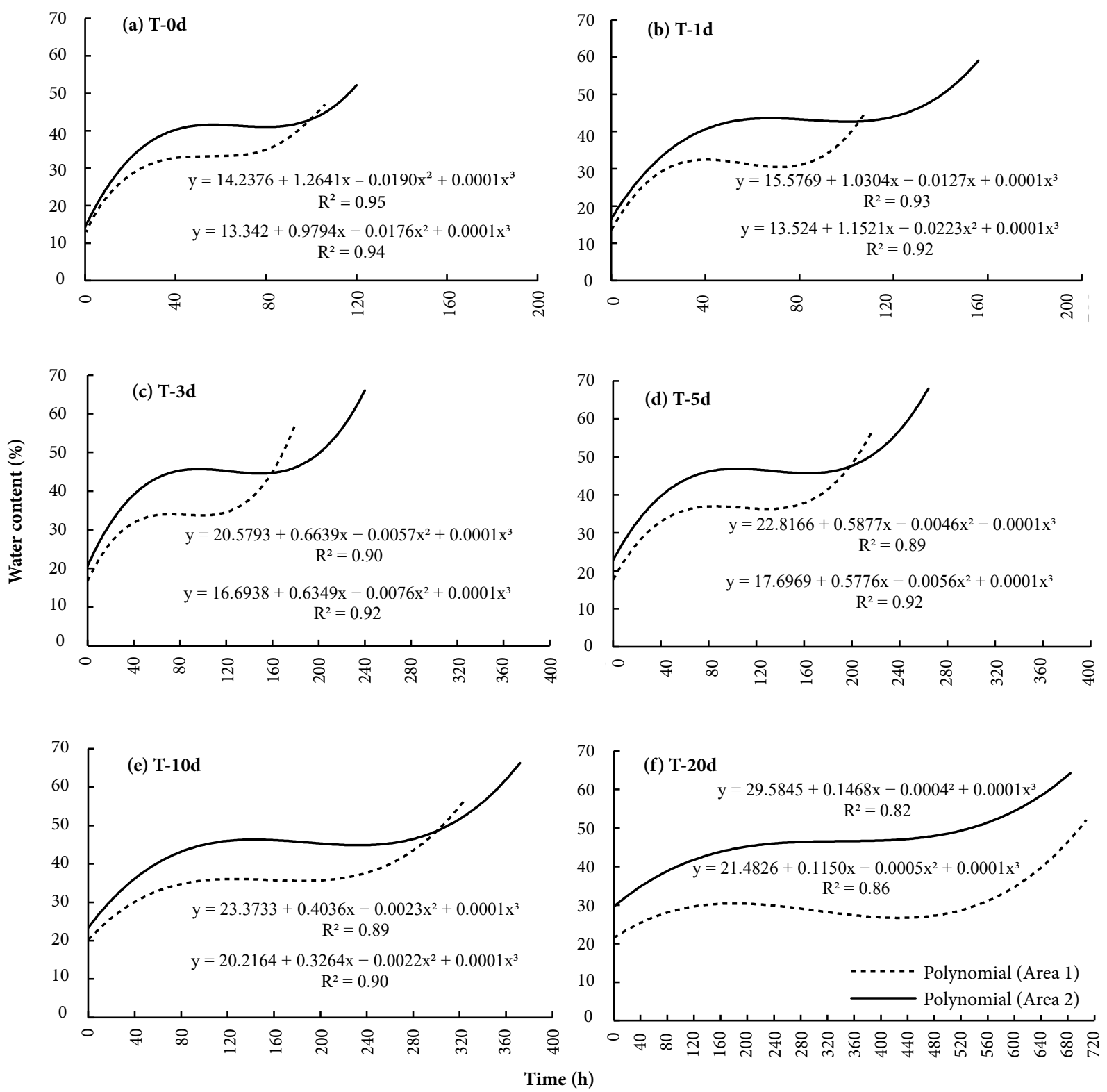

Figure 1. Imbibition curves during germination of G. klotzschiana seeds collected in Area 1 (area subject to periodic flooding) and in Area 2 (area not subject to periodic flooding), when submitted to different hypoxia periods.

Hypoxia periods (number of days under controlled flooding): (a) T-0d: control; (b) T-1d: one day; (c) T-3d: three days; (d) T-5d: five days; (e) T-10d: ten days; (f) T-20d: twenty days.

Table 1. Germination, first germination count and germination speed index in G. klotzschiana seeds submitted to different hypoxia periods, originating from two areas after 21 days of germination testing.

\begin{tabular}{|c|c|c|c|c|c|c|}
\hline \multirow{2}{*}{ Treatments } & \multicolumn{2}{|c|}{ Germination } & \multicolumn{2}{|c|}{ FGC } & \multicolumn{2}{|c|}{ GSI } \\
\hline & Area 1 & Area 2 & Area 1 & Area 2 & Area 1 & Area 2 \\
\hline & \multicolumn{4}{|c|}{$\%$} & \multicolumn{2}{|c|}{ seedlings.day ${ }^{-1}$} \\
\hline T-0d & $85 \mathrm{aA}^{*}$ & $84 \mathrm{aA}$ & $80 \mathrm{aA}$ & $12 \mathrm{aB}$ & $2.26 \mathrm{aA}$ & $1.61 \mathrm{aB}$ \\
\hline $\mathrm{T}-1 \mathrm{~d}$ & $90 \mathrm{aA}$ & $81 \mathrm{aA}$ & $86 a A$ & $19 \mathrm{aB}$ & $2.78 \mathrm{aA}$ & $1.62 \mathrm{aB}$ \\
\hline $\mathrm{T}-3 \mathrm{~d}$ & $84 \mathrm{aA}$ & $66 \mathrm{bB}$ & $80 \mathrm{aA}$ & $7 \mathrm{aB}$ & $2.71 \mathrm{aA}$ & $1.19 \mathrm{bB}$ \\
\hline $\mathrm{T}-5 \mathrm{~d}$ & $78 \mathrm{aA}$ & $63 \mathrm{bB}$ & $75 \mathrm{aA}$ & $5 \mathrm{aB}$ & $2.68 \mathrm{aA}$ & $1.14 \mathrm{bB}$ \\
\hline
\end{tabular}


Table 1. Continued...

\begin{tabular}{|c|c|c|c|c|c|c|}
\hline \multirow{2}{*}{ Treatments } & \multicolumn{2}{|c|}{ Germination } & \multicolumn{2}{|c|}{ FGC } & \multicolumn{2}{|c|}{ GSI } \\
\hline & Area 1 & Area 2 & Area 1 & Area 2 & Area 1 & Area 2 \\
\hline & \multicolumn{4}{|c|}{$\%$} & \multicolumn{2}{|c|}{ seedlings.day ${ }^{-1}$} \\
\hline $\mathrm{T}-10 \mathrm{~d}$ & $70 \mathrm{aA}$ & $63 \mathrm{bA}$ & $66 \mathrm{bA}$ & $10 \mathrm{aB}$ & $2.68 \mathrm{aA}$ & $1.32 \mathrm{bB}$ \\
\hline T-20d & $45 \mathrm{bA}$ & $31 \mathrm{cB}$ & $5 \mathrm{cA}$ & ObA & $0.77 \mathrm{bA}$ & $0.58 \mathrm{cA}$ \\
\hline CV (\%) & \multicolumn{2}{|c|}{13.5} & \multicolumn{2}{|c|}{21.7} & \multicolumn{2}{|c|}{13.7} \\
\hline
\end{tabular}

* Lowercase letters compare values in the same column and uppercase letters in the same row, per test; means followed by distinct letters differ significantly by the ScottKnott test $(\alpha=0.05)$. FGC: first germination count; GSI: germination speed index. Area 1: area subject to periodic flooding; Area 2: area not subject to periodic flooding; treatments with the number of days under controlled flooding: T-0d: control; T-1d: one day; T-3d: three days; T-5d: five days; T-10d: ten days; T-20d: twenty days.

Stability in the water absorption during Phase II is common in species that have well-defined three-phase germination (Bewley et al., 2013). It was observed that seeds remaining for a longer period under oxygen restriction extended this phase proportionally. Seeds from treatment T-20d had the highest mortality rates (flaccid and yellowish internal tissues) and the lowest germination (Table 1). In this case, the death of some seeds could have started by lipid peroxidation caused by free radicals (Palermo et al., 2015; Sevcikova et al., 2011), which possibly caused the loss of cell turgor by induced death. Biological membranes are semipermeable barriers and the maintenance of their functions depends on their integrity (Kraffe et al., 2007).

The onset of root protrusion (Phase III) is basically a physical process (Bewley et al., 2013) and water ingress is essential for cell expansion. Later, the higher water absorption is justified by the need to transport previously hydrolyzed compounds to the embryonic axis, which are necessary for forming a new seedling.

Seeds from both areas had different behaviors in the control treatment regarding Phase III, whereas those from Area 1 started this phase $30 \mathrm{~h}$ before seeds from the other area. This is an indication of the higher quality and probably greater tolerance to hypoxia of the seeds in this lot (Area 1). Considering all treatments, seeds collected in Area 1 generally reached Phase III before those collected in Area 2, showing greater vigor of Area 1 seeds. Vigor involves energy biosynthesis and associated metabolic compounds to cellular activity and membrane integrity (AOSA, 1983), which are critical in tolerating environmental stresses during germination (Xiaolin et al., 2017).

Germination showed significant differences between treatments in the same area and between areas. For Area 1, only treatment T-20d was inferior to the others (45\%), and T-1d seeds had the highest index (90\%). For Area 2, seed germination of treatments T-0d and T-1d were higher, with $84 \%$ and $81 \%$, respectively; $\mathrm{T}-3 \mathrm{~d}, \mathrm{~T}-5 \mathrm{~d}$ and $\mathrm{T}-10 \mathrm{~d}$ were statistically equal and higher than T-20d, for which $31 \%$ germination was verified. Considering the same treatment between areas, only the control (T-0d) and T-1d did not differ statistically (Table 1).

Seeds from the two collection areas submitted to the treatments also presented different results regarding vigor. For Area 1, the FGC was significantly higher for T-0d (80\%), T-1d (86\%), T-3d (80\%) and T-5d (75\%) treatments from stress due to hypoxia; these differed from T-10d (66\%) and T-20d (5\%). For Area 2 seeds, only seeds that remained for 20 days under oxygen restriction (T-0d) presented different results from the others. When FGC from the same treatments in relation to the two areas was compared, seeds from Area 1 were superior to those from Area 2 in most treatments, except for T-20d (Table 1).

The GSI of seeds from Area 1 was higher than in T-1d (2.78), and they were statistically different from the others only in T-20d. This test showed higher values for T-0d (1.61) and T-1d (1.62) seeds in Area 2, and the lowest index was found for T-20d (0.58), which was inferior to the others. When the GSI was compared between the same treatments in relation to the areas, only T-20d seeds showed values which did not differ statistically (Table 1).

Germination was similar in both areas when there was no stress effect, but slower for Area 2 seeds. Higher germination values and mainly seed vigor for most treatments applied to Area 1 seeds indicated that germination velocity, especially revealed by the FGC, is the most important factor to be considered in branquilho's adaptability to flooding (Table 1). Seeds with greater vigor are more tolerant to environmental stresses, because these seeds need to germinate rapidly after dispersal under a probable oxygen restriction condition. Greater tolerance to flooding in germination is genetically regulated (Colmer et al., 2013), and it includes the ability to initiate and maintain the carbohydrate catabolism required for anaerobic respiration and thus sustain energy supply and maintenance (Colmer et al., 2013; Kirk et al., 2013). The importance of carbohydrate utilization during germination under hypoxia condition was addressed by Ferreira et al. (2009) in Himatanthus succubus seeds, a typical tree species of periodically flooded areas. 
When analyzing the $\mathrm{T}-1 \mathrm{~d}$ treatment in relation to the $\mathrm{T}-0 \mathrm{~d}$, it was observed that the application period of seed stress occurred during Phase I and consequently the effect of this adverse factor was low or null. The controlled flooding stress effect reached a longer period in Phase II germination for the T-3d, T-5d and T-10d treatments. Although Phase II is characterized as a physiological rest period, it is important in the physiological response of seeds, since in this period begins the hydrolysis of the reserves and the fight against free radicals (Wang et al., 2015). The low hypoxia effect on seeds from Area 1 for these treatments (T-3d, T-5d and T-10d) was possibly due to the greater efficiency in controlling reactive oxygen species (ROS) present in the cells during the treatment period with lower oxygen availability in the environment. However, cellular damage due to the lower efficiency in controlling ROS may have occurred in the seeds of these same treatments from Area 2, and mainly in the T-20d treatment of both areas, where the lowest germination and vigor indices occurred.

Thus, maintaining cellular integrity throughout the stress period in which Area 1 seeds were exposed is possibly related to the time when this adverse effect was present during germination and the ability of the seeds to counteract this adverse condition. As Phase II is a preparatory step for germination (Bewley et al., 2013), the lack of oxygen only delayed this process. Maintaining seed quality during this period is probably linked to the synthesis of antioxidant compounds (López et al., 2011; Sharma et al., 2012), such as superoxide dismutase and catalase enzymes (Iannone et al, 2012; Luo et al., 2013).

Abnormal seedling formation was low, ranging from 0 to $9 \%$, with the maximum being recorded for T-10d (Area 1) and T-3d (Area 2). The number of dead seeds (DS) was highlighted for the treatments in which the seeds remained up to twenty days under hypoxia (T-20d). The number of non-germinated seeds (NGS) in this treatment represented 24\% and 22\% (DS) for Area 1. In Area 2, T-20d presented $22 \% \mathrm{NGS}$ and $37 \% \mathrm{DS}$. The amount of empty seeds was similar in all treatments in both areas. Seed viability was between 0 and $4 \%$ of total germination. Thus, the number of dormant seeds had little influence on the distinction between treatments and lots (Table 2).

The number of non-germinated and dead seeds increased overall in both evaluated areas as stress was more pronounced, especially for T-20d. Seeds in this oxygen-restricted condition may limit cell division and elongation due to energy scarcity (Takahashi et al., 2011), as well as damage by the presence of reactive oxygen species (Andrade et al., 2010).

Seeds eventually enter into dormancy when some environmental stress occurs (Finch-Savage \& LeubnerMetzger, 2006), at least until environmental conditions become favorable (Huang et al., 2010). However, stress due to lack of oxygen for the seeds of this species, especially for a period longer than ten days, represented a loss in viability for most seeds. Hypoxia stress can influence seed germination (Ferreira et al., 2009; Gonçalves et al., 2012), and depending on the flooding time seedlings may lose their viability (Medina et al., 2009) and/or its development may be compromised (Pisicchio et al., 2010).

Species adapted to periodically flooded environments, such as G. klotzschiana, develop strategies that allow them to establish and survive at environments with low oxygen concentrations (Jackson \& Ram, 2003). Seeds need to take advantage of the short and unpredictable periods when the water level drops to germinate (Marques \& Joly, 2000). Therefore, high seed vigor becomes essential in plant establishment, especially for branquilho that has autochoric dispersion, in which seeds can remain in a flooded site for some days. Note that seeds are first released by "bursting" of fruits (spring/summer) and may eventually colonize by hydrochory in other places less prone to flooding.

Table 2. Percentage of abnormal seedlings, dead seeds, empty seeds, non-germinated seeds, and viable G. klotzschiana seeds harvested in two areas under different flooding regimes and submitted to six periods of hypoxia.

\begin{tabular}{|c|c|c|c|c|c|c|c|c|c|c|}
\hline \multirow{2}{*}{ Treatments } & \multicolumn{2}{|c|}{ AS } & \multicolumn{2}{|c|}{ DS } & \multicolumn{2}{|c|}{ ES } & \multicolumn{2}{|c|}{ NGS } & \multicolumn{2}{|c|}{ VS } \\
\hline & Area 1 & Area 2 & Area 1 & Area 2 & Area 1 & Area 2 & Area 1 & Area 2 & Area 1 & Area 2 \\
\hline & \multicolumn{10}{|c|}{$\%$} \\
\hline T-0d & $0^{*}$ & 0 & 1 & 2 & 5 & 4 & 9 & 10 & 1 & 4 \\
\hline $\mathrm{T}-1 \mathrm{~d}$ & 4 & 1 & 0 & 4 & 5 & 8 & 1 & 6 & 0 & 1 \\
\hline $\mathrm{T}-3 \mathrm{~d}$ & 2 & 9 & 3 & 3 & 6 & 5 & 5 & 17 & 2 & 2 \\
\hline $\mathrm{T}-5 \mathrm{~d}$ & 0 & 7 & 2 & 11 & 13 & 6 & 7 & 13 & 1 & 0 \\
\hline $\mathrm{T}-10 \mathrm{~d}$ & 9 & 5 & 1 & 18 & 8 & 7 & 12 & 7 & 2 & 0 \\
\hline T-20d & 0 & 3 & 22 & 37 & 9 & 7 & 24 & 22 & 0 & 0 \\
\hline
\end{tabular}

* Percentage values; Area 1: area subject to periodic flooding; Area 2: area not subject to periodic flooding; AS: abnormal seedlings; DS: dead seeds; ES: empty seeds; NGS: non-germinated seeds; VS: viable G. klotzschiana seeds (VS); treatments with the number of days under controlled flooding: T-0d: control; T-1d: one day; T-3d: three days; T-5d: five days; T-10d: ten days; T-20d: twenty days. 
In projects to recompose flood-prone areas, such results suggest that selecting seeds from oxygen-restricted sites may be fundamental for branquilho plants to grow. Schmiede et al. (2009) and Gattringer et al. (2017) highlight that the restoration of flooded areas should contain seeds and/or seedlings adapted to this condition. Moreover, flooding may intensify in the next years due to climate change (Frigerio et al., 2018), further increasing the importance of this strategy of matrix selection for rebuilding these environments.

\section{CONCLUSION}

Gymnanthes klotzschiana seeds harvested from areas subject to flooding are more tolerant to hypoxia, thus, they are recommended for reforestation projects in this area.

\section{ACKNOWLEDGEMENTS}

The authors would like to acknowledge the Centro de Ciências Agroveterinárias of Universidade do Estado de Santa Catarina for making available the equipment and inputs used in this research. The authors also would like to acknowledge the research group of the Laboratório de Sementes Florestais for their supports in both exams and collection of seeds in the field work.

\section{SUBMISSION STATUS}

Received: 4 Sept. 2017

Accepted: 12 Aug. 2019

Associate editor: Juliana Müller Freire

(D) 0000-0002-4758-2533

\section{CORRESPONDENCE TO}

\section{Émerson Couto da Rocha}

Fundação Estadual de Proteção Ambiental Henrique Luiz Roessler (Fepam), Rua Fagundes dos Reis, 1.155, CEP 99020-080, Passo Fundo, RS, Brasil

e-mail: emersoneng@live.com

\section{REFERENCES}

Andrade ER, Melo-Sterza FA, Senada MM, Alfieri, AA. Consequências da produção das espécies reativas de oxigênio na reprodução e principais mecanismos antioxidantes. Revista Brasileira de Reprodução Animal 2010; 34(2): 79-85.

Association of Official Seed Analysts - AOSA. Seed vigour testing handbook. East Lansing; 1983.

Bailey-Serres J, Fukao T, Gibbs DJ, Holdsworth MJ, Lee SC, Licausi $\mathrm{F}$ et al. Making sense of low oxygen sensing. Trends in Plant Science 2012; 17(3): 129-138. 10.1016/j.tplants.2011.12.004

Barddal ML. A influência da saturação hídrica na distribuição de oito espécies arbóreas da floresta ombrófila mista aluvial do rio Iguaçu, Paraná, Brasil [dissertation]. Curitiba: Universidade Federal do Paraná; 2006.
Bewley JD, Bradford K, Hilhorst H, Nonogaki H. Physiology of development, germination and dormancy. 3rd ed. New York: Springer; 2013.

Brancalion PHS, Rodrigues RR, Gandolfi S, Kageyama PY, Nave AG, Gandara FB et al. Instrumentos legais podem contribuir para a restauração de florestas tropicais biodiversas. Revista Árvore 2010; 34(3): 455-470. 10.1590/S0100-67622010000300010

Brasil. Ministério da Agricultura, Pecuária e Abastecimento. Regras para análise de sementes. Brasília, DF; 2009.

Carvalho NM, Nakagawa J. Sementes: ciência, tecnologia e produção. 5th ed. Jaboticabal: Funep; 2012.

Colmer TD, Armstrong W, Greenway H, Ismail AM, Kirk GJD, Atwell BJ. Physiological mechanisms of flooding tolerance in rice: transient complete submergence and prolonged standing water. Progress in Botany 2013; 75: 255-307. 10.1007/978-3-642-38797-5_9

Cosmo NL, Nogueira AC, Lima JG, Kuniyoshi YS. Morfologia de fruto, semente e plântula de Sebastiania commersoniana, Euphorbiaceae. Revista Floresta 2010; 40(2): 419-428. 10.5380/rf.v40i2.17837

Crawford RMM, Brandle R. Oxygen deprivation stress in a changing environment. Journal of Experimental Botany 1996; 47(2): 145-159. 10.1093/jxb/47.2.145

Ferreira CS, Piedade MTF, Bonates LC. Germinação de sementes e sobrevivência de plântulas de Himatanthus sucuuba (Spruce) Wood. em resposta ao alagamento, nas várzeas da Amazônia Central. Acta Amazonica 2006; 36(4): 413-418. 10.1590/S004459672006000400003

Ferreira CS, Piedade MTF, Franco AC, Gonçalves JFC, Junk WJ. Adaptive strategies to tolerate prolonged flooding in seedlings of floodplain and upland populations of Himatanthus sucuuba, a Central Amazon tree. Aquatic Botany 2009; 90(3): 246-252. 10.1016/j.aquabot.2008.10.006

Ferreira PI, Gomes JP, Batista F, Bernardi AP, Costa NCF, Bortoluzzi RLC et al. Espécies potenciais para recuperação de áreas de preservação permanente no planalto catarinense. Floresta e Ambiente 2013; 20(2):173-182. 10.4322/floram.2013.003

Finch-Savage WE, Leubner-Metzger G. Seed dormancy and the control of germination. New Phytologist 2006; 171(3): 501-523.

Frigerio S, Schenato L, Bossi G, Mantovani M, Marcato G, Pasuto A. Hands-on experience of crowdsourcing for flood risks. An android mobile application tested in Frederikssund, Denmark. International Journal of Environmental Research and Public Health 2018; 15(9): 1-19. 10.3390/ijerph15091926

Gattringer JP, Donath TW, Eckstein RL, Ludewig K, Otte A, HarvolkSchoning S. Flooding tolerance of four floodplain meadow species depends on age. Plos One 2017; 12(5): 1-15. 10.1371/journal. pone. 0176869

Gonçalves JFC, Melo EGF, Silva CEM, Ferreira MJ, Justino GC. Estratégias no uso da energia luminosa por plantas jovens de Genipa spruceana Steyerm submetidas ao alagamento. Acta Botanica Brasilica 2012; 26(2): 391-398. 10.1590/S0102-33062012000200014

Huang X, Schmitt J, Dorn L, Griffith C, Effgen S, Takao S et al. The earliest stages of adaptation in an experimental plant population: strong selection on QTLS for seed dormancy. Molecular Ecology 2010; 19(7): 1335-1351. 10.1111/j.1365-294X.2010.04557.x

Iannone MF, Rosales EP, Groppa MD, Benavides MP. Reactive oxygen species formation and cell death in catalase-deficient tobacco 
leaf discs exposed to paraquat. Biological Trace Element Research 2012; 146(2): 246-255. 10.1007/s12011-011-9244-1

Instituto Brasileiro de Geografia e Estatística - IBGE. Manual Técnico da Vegetação Brasileira: Sistema fitogeográfico Inventário das formações florestais e campestres Técnicas e manejo de coleções botânicas procedimentos para mapeamentos. Rio de Janeiro; 2012.

Jackson MB, Ram PC. Physiological and molecular basis of susceptibility and tolerance of rice plants to complete submergence. Annals of Botany 2003; 91(2): 227-241.

Jardim Botânico do Rio de Janeiro - JBRJ. Gymnanthes klotzschiana Müll.Arg. Flora do Brasil 2020 [Internet]. [2018?] [cited 2018 Aug. 29]. Available from: https://bit.ly/2OWgXuW

Kato-Noguchi H. Pyruvate metabolism in rice coleoptiles under anaerobiosis. Plant Growth Regulation 2006; 50(1): 41-46. 10.1007/ s10725-006-9124-4

Kirk GJD, Greenway H, Atwell BJ, Ismail AM, Colmer TD. Adaptation of rice to flooded soils. Progress in Botany 2013; 75: 215-253.

Kozlowski TT. Responses of woody plants to flooding and salinity. Tree Physiology Monograph 1997; 7(1): 1-29.

Kraffe E, Marty Y, Guderley H. Changes in mitochondrial oxidative capacities during thermal acclimation of rainbow trout Oncorhynchus mykiss: Roles of membrane proteins, phospholipids and their fatty acid compositions. Journal of Experimental Botany 2007; 210: 149-165.

Li J, Wang Y, Pritchard HW, Wang X. The fluxes of $\mathrm{H} 2 \mathrm{O} 2$ and $\mathrm{O} 2$ can be used to evaluate seed germination and vigor of Caragana korshinskii. Planta 2014; 239(6): 1363-1373.

López MA, Vicente J, Kulasekaran S, Vellosillo T, Martínez M, Irigoyen $\mathrm{ML}$ et al. Antagonistic role of 9-lipoxygenase-derived oxylipins and ethylene in the control of oxidative stress, lipid peroxidation and plant defence. The Plant Journal 2011; 67(3): 447-458. 10.1111/j.1365-313X.2011.04608.x

Luo X, Wu J, Li Y, Nan Z, Guo X, Wang Y et al. Synergistic effects of GhSOD1 and GhCAT1 overexpression in cotton chloroplasts on enhancing tolerance to methyl viologen and salt stresses. Plos One 2013; 8(1): 1-11. 10.1371/journal.pone.0054002

Magneschi L, Perata P. Rice germination and seedling growth in the absence of oxygen. Annals of Botany 2009; 103(2): 181-196. $10.1093 / \mathrm{aob} / \mathrm{mcn} 121$

Maguire JD. Speed of germination: aid in selection and evaluation for seedling emergence and vigor. Crop Science 1962; 2(2): 176-177.

Marcos-Filho J. Fisiologia de sementes de plantas cultivadas. 2 nd ed. Londrina: Abrates; 2015.

Marques MCM, Joly CA. Germinação e crescimento de Calophyllum brasiliense (Clusiaceae), uma espécie típica de florestas inundadas. Acta Botanica Brasilica 2000; 14(1): 113-120. 10.1590/S010233062000000100010

Medina CL, Sanches MC, Tucci MLS, Sousa CAF, Cuzzuol GRF, Joly CA. Erythrina speciosa (Leguminosae-Papilionoideae) under soil water saturation: morphophysiological and growth responses. Annals of Botany 2009; 104(4): 671-680.

Narsai R, Whelan J. How unique is the low oxygen response? An analysis of the anaerobic response during germination end comparison with abiotic stress in rice and Arabidopsis. Frontiers in Plant Science 2013; 349(4): 1-14. 10.3389/fpls.2013.00349
Palermo FF, Risso WE, Simonato JD, Martinez CBR. Bioaccumulation of nickel andits biochemical and genotoxic effects on juveniles of the neotropical fish Prochilodus lineatus. Ecotoxicology and Environmental Safety 2015; 116: 19-28. 10.1016/j.ecoenv.2015.02.032

Pisicchio CM, Bianchini E, Pimenta JA, Sert MA, Davanso-Fabro VA, Medri ME. Heliocarpus popayanensis (Malvaceae) tolera a hipóxia do substrato? Acta Scientiarum - Biological Sciences 2010; 32(2): 201-209.

Rodrigues RR, Lima RAF, Gandolfi S, Nave AG. On the restoration of high diversity forests: 30 years of experience in the Brazilian Atlantic Forest. Biological Conservation 2009; 142(6): 1242-1251. 10.1016/j.biocon.2008.12.008

Santos SRG, Aguiar IB. Efeito da temperatura na germinação de sementes de Sebastiania commersoniana (Baillon) Smith \& Downs separadas pela coloração do tegumento. Scientia Forestalis 2005; 69: 77-83.

Scarano FR, Pereira TS, Rôças G. Seed germination during floatation and seedling growth of Carapa guianensis, a tree from floodprone forests of the Amazon. Plant Ecology 2003; 168(2): 291-296. 10.1023/A:1024486715690

Schmiede R, Donath TW, Otte A. Seed bank development after the restoration of alluvial grassland via transfer of seed-containing plant material. Biological Conservation 2009; 142(2): 404-413. 10.1016/j. biocon.2008.11.001

Sevcikova M, Modra H, Slaninova A, Svobodova Z. Metals as a cause of oxidative stress in fish: a review. Veterinarni Medicina 2011; 56(11): 537-546.

Sharma P, Jha AB, Dubey RS, Pessarakli M. Reactive oxygen species, oxidative damage, and antioxidative defense mechanism in plants under stressful conditions. Journal of Botany 2012; 1-26. $10.1155 / 2012 / 217037$

Silva AC, Higuchi $\mathrm{H}$, van den Berg E, Nunes $\mathrm{MH}$, Carvalho DA. Florestas inundáveis: ecologia, florística e adaptações das espécies. Lavras: Editora UFLA; 2012.

Takahashi H, Saika H, Matsumura H, Nagamura Y, Tsutsumi N, Nishizawa NK et al. Cell division and cell elongation in the coleoptile of rice alcohol dehydrogenase 1-deficient mutant are reduced under complete submergence. Annals of Botany 2011; 108(2): 253-261. $10.1093 / \mathrm{aob} / \mathrm{mcr} 137$

Villa-Hernández JM, Dinkova TD, Aguilar-Caballero R, RiveraCabrera F, Sánchez de Jiménez E, Pérez-Flores LJ. Regulation of ribosome biogenesis in maize embryonic axes during germination. Biochimie 2013; 95(10): 1871-1879. 10.1016/j.biochi.2013.06.011

Wang WL, Liu SJ, Song SQ, Moller IM. Proteomics of seed development, desiccation tolerance, germination and vigor. Plant Physiology and Biochemistry 2015; 86(1): 1-15. 10.1016/j. plaphy.2014.11.003

Weitbrecht K, Müller K, Leubner-Metzger G. First off the mark: early seed germination. Journal of Experimental Botany 2011; 62(10): 3289-3309. 10.1093/jxb/err030

Xiaolin W, Fen N, Xiuli H, Wei W. Genetic modification for improving seed vigor is transitioning from model plants to crop plants. Frontiers in Plant Science 2017; 8(8): 1-7. 10.3389/fpls.2017.00008 